\title{
Development of Management Model to Build Students' Self Resilience from Drug Abuse
}

\author{
Japar Sidik \\ \{ sidikjapar825@gmail.com \} \\ Education Administration Study Program, Postgraduate, State University of Medan, Medan, \\ Indonesia $^{2}$
}

\begin{abstract}
Self-resilience needs to be owned by every teenager, including high school students so that they can avoid various adverse influences one of which is drug abuse. The aim of this study is to produce products in the form of management models those are appropriate to be used to build students' self-resilience from drug abuse, and measure the effectiveness of product development models to build students self-resilience from drug abuse. This research includes the type of research and development that refers 4-D model, namely defines, design, develop and disseminate. Research subjects were students of SMA Negeri 1 Tanjung Tiram, Batubara Regency. The results of the study show that the management model product developed has received an assessment form an expert validation, the assessment results stated that the products were appropriate to be used to build students' self-resilience from drug abuse, and the product developed has been tested in small groups and field test, the results of the tested showed effective products used to build students' self-resilience from drug abuse. Thus it was concluded that the management model developed was categorized as feasible and effective to be used to build students' self-resilience from drug abuse.
\end{abstract}

Keywords: Management model, self-resilience, drug abuse.

\section{Introduction}

Generally high school students are teenagers who are very vulnerable to outside influences. The existence of various demands on the basis of its growth and development makes teenagers very vulnerable to any interference that can cause problems in their lives both personally and social problems. Of course the problems and adverse conditions that arise and are experienced by students (teenager) will not occur if the students have strong self-resilience so that they avoid all bad influences.

A students (teenager) needs to have a strong self-resilience that can be used as a stronghold of self-resilience to counteract the various influences and challenges that befall him. Students who have strong and positive self-resilience will certainly be able to fortify themselves from various bad influences that come from both inside and outside themselves. Conversely students who do not have strong self-resilience tend to think and behave in the wrong way which will have a negative impact on the life of the student itself.

Self-resilience can be interpreted as the ability of teenagers to adapt to conditions of change and pressure through flexible and healthy ways [1]. Self-resilience can also be interpreted as personal resilience. Personal resilience is a dynamic condition or appearance of a person that implies persistence, resilience and ability to develop the power to deal with and 
overcome all forms of threats, challengers, obstacles and disturbances that come from within and from outside that directly or indirectly endanger integrity, identity, existence and struggle to pursue goals and ideals according to their vision (Soedarsono, 2000: 9). A person selfresilience can be also being in the form of adversity quotient. Adversity quotient is a person's ability to fight and overcome problems, obstacles or difficulties they have and will turn them into opportunities for success [3].

Self-resilience is important for high school students because at this age it is a time that always wants to experiment with new things and is prone to negative influences such as being involved in alcohol, smoking, falling into sexual life or free sex even involved in drug abuse. Currently the problem that is experienced by students (teenagers) is drug abuse. Drug threats continue to overshadow people's lives, causing parents to worry about the safety and safety of their children's future [4].

The current phenomenon of drug abuse by high school students (teenagers) shows that in this phase, teenagers or students are in a very vulnerable period due to lack of experience and understanding of the knowledge provided about the dangers of drugs themselves. The young generation's ignorance of drugs and personality turbulence and drug availability are the main problems in fighting drugs [5]. Drug abuse is caused by several factors, namely social environmental factors such as curiosity motives, opportunities, facilities and infrastructure, and personality factors such as low self-esteem, emotional and mental [6]. Factors causing drug abuse are family factors, personality factors and opportunity factors [5].

The high school students need to be equipped with strong and positive self-resilience to avoid association and lifestyle that can damage themselves including avoiding drug abuse. To be able build self-resilience of students, in order to avoid the influence of drug abuse it is necessary to develop a management model that can develop awareness of critical thinking, self-confidence, play and active role, be responsible and encourage students' ability to have the depth of interpreting social phenomena in their lives including the phenomenon of influence drug abuse and its dangers.

Management is to organize and regulate all activities so that they can be carried out as well as possible, precisely, directed and completed and can be accounted for [7]. Management can also be interpreted as a process or framework, which involves the guidance or direction of a group of people towards organizational goals or real intentions [8]. The main functions of management included planning, organizing, actuating and controlling.

This aim of study is to produce product in the form of appropriate management models to build students 'self-resilience from drug abuse, and measure the effectiveness of product development management models to build students' self-resilience from drug abuse.

\section{Methodology}

This study uses a research and development approach modified from Borg and Gall [9]. The development model used in this research and development is 4-D development model proposed by Thiagarajan and Semmel [10], which consists of four stages, namely define, design, develop, and disseminate.

The define phase included 5 (five) main steps, namely: front end analysis, student analysis, task analysis, concept analysis, and formulation of objectives. The analysis was conducted at SMA Negeri 1 Tanjung Tiram, Batubara Regency by observing, conducting indepth interview with teachers about student 'self-resilience (teenagers) and conducting Focus 
Group Discussion (FGD) for several students (teenagers) who were used to raise and establish basic problems to build student 'self-resilience especially against drug abuse.

The design phase is carried out to prepare materials and design products to be developed, including the preparation of validation questionnaire instruments by material and media experts, as well as the effectiveness questionnaire used to see the valid and effective models developed. The media developed in the form of modules about the management model to build students self-resilience from drug abuse that contains introduction, types and dangers of drugs, model of students self-resilience management from drug abuse (planning, organizing, actuating and controlling).

The development phase was carried out through 2 (two) steps, namely expert assessment followed by revisions and development tests. The purpose of this development phase is to produce a final form of a module management model to build students self-resilience from drug abuse after going through a process of validation and revision based on expert advice. Expert validation included a validation of material expert who assess the product on aspects of content feasibility, language feasibility and presentation of feasibility aspects, and validation of media experts who assess the product in terms of module display, language feasibility and product feasibility.

The disseminate phase is the final stage in which the development product is promoted so that it can be accepted by users both individually, in a group or system. In the deployment phase which was seen was the developed modules, their effectiveness could be seen from the effectiveness test by using students' self-resilience from drug abuse questionnaires.

The research and development subject consists of: two validators' questionnaire instruments; two expert validators namely materials experts and media experts; and SMA Negeri 1 Tanjung Tiram students. Data collection techniques and instruments use interview guidelines, observation, questionnaire and documents. Data analysis was carried out in several stages: First, analyzing the needs, objectives, materials, preparation, implementation and evaluation of the development of students' self-resilience management models through interactive analysis with data collection steps, data reduction, data display and conclusions; and second, analyzing the effectiveness of students' self-resilience management models by analyzing the results of student questionnaires based on the result of field tests.

\section{Result and Discussion}

\subsection{Development Research}

The result of this research and development are management models to build students' self-resilience from drug abuse, developed by the 4-D method proposed by Thiagarajan and Semmel [10] including define, design, develop, and disseminate.

In the define phase, an analysis of the needs of students as teenagers is done by analyzing students' self-resilience from the influence of drug abuse by conducting Focus Group Discussion (FGD) to 10 students including tenacity, resilience, ability to develop self-strength, ability to face challenges that come. The results of interviews with Counseling Guidance teachers and FGD result with 10 students (recommendation of Counseling Guidance teachers) in SMA Negeri 1 Tanjung Tiram obtained information that some students tended to have smoking habits, skipping school, lack of learning enthusiasm, low self-esteem, pessimism, easily influenced by friends, lack of understanding of types and dangers of drugs, and have negative self-resilience. In addition, high school students quality as teenagers and make it 
possible to be a development model. Based on the result of the analysis in the define phase, it was determined that the products developed in the form of modules.

The planning or design phase is a stage of develop a management model to build students' self-resilience from drug abuse whose development is arranged in modules and validation questionnaire instruments by material experts and media experts as well as questionnaires on the effectiveness of product develop.

The development phase was carried out through two steps, namely assessment by material experts and media experts followed by revisions based on expert suggestions and development testing. The results of the development stage include the result of expert material validation and media expert validation result.

The disseminate phase is the final stage in research and development where the development products are promoted so that they can be accepted by users, individuals, group or systems. This stage is the stage of using the device that has been developed on a wider scale and aims to test the feasibility of using the product. After the product is declared valid by the validator, the next step is the deployment stage. In the deployment phase which is seen or assessed is the effectiveness of the module being developed, its effectiveness can be seen from the effectiveness test by using a questionnaire sheet about students 'self-resilience from drug abuse. The effectiveness of the product was obtained through field tests conducted on SMA Negeri 1 Tanjung Tiram students, namely a small group test with 10 students and a large group with 30 students.

\subsection{Product Validation Results}

Products are developed in the form of modules on management models to build students' self-resilience from drug abuse. The products developed are then evaluated or validated by material expert and media expert. Validation result by material expert can be seen in table 1 .

Table 1. Material Expert Validation Results

\begin{tabular}{|c|c|c|c|}
\hline No. & Assessment Indicator & $\begin{array}{l}\text { Average } \\
\text { Score }\end{array}$ & Criteria \\
\hline 1 & Feasibility of Content & 3.4 & Good \\
\hline 2 & Feasibility of Language & 3.8 & Good \\
\hline 3 & Feasibility of Presentation & 3.4 & Good \\
\hline & Average & 3.5 & Good \\
\hline
\end{tabular}

Assessments from material expert obtained average rating with good categories as well as some suggestions from material expert such as more compacted material and supporting images/ illustrations of more adapted material. Based on the result or subsequent evaluation, revisions were made according to the suggestions from the material expert. The result of the validation by material expert concluded that the module developed was declared valid and feasible to use according to the feasibility of the content, language, and the feasibility of presenting the material.

The products developed were also evaluated and validated by media expert on aspects of module display, language feasibility and product feasibility. Validation results by media expert can be seen in the table 2 .

Table 2. Media Expert Validation Results

\begin{tabular}{cccc}
\hline No & Assessment Indicator & $\begin{array}{c}\text { Average } \\
\text { Score }\end{array}$ & Criteria \\
\hline 1 & Module Display & 3.6 & Good \\
\hline
\end{tabular}




\begin{tabular}{cccl}
\hline No & Assessment Indicator & $\begin{array}{c}\text { Average } \\
\text { Score }\end{array}$ & Criteria \\
\hline 2 & Feasibility of Language & 3.6 & Good \\
3 & Feasibility of Product & 4.2 & Very Good \\
Average & 3.8 & Good \\
\hline
\end{tabular}

The results of validation by media expert obtained an average rating with good categories and for the feasibility of the product obtained an assessment with a very good category, with some suggestions from media expert including improving the size of the module so that it is easy to use and improve the layout of text and images. Based on the results of validation by media expert it was conclude that the developed modules were declared valid and feasible to use.

\subsection{Product Effectiveness}

After the revision is done according to be the suggestions of the expert validator and module developed has been declared valid and feasible, then the next steps are the stage of packaging and distributing the product. In the deployment phase, the effectiveness of the product will be tested using a questionnaire instrument given to high school students as the target of the user. The effectiveness test was carried out in two stages: small group test (10 students) and large group test (30 students). The results of the product effectiveness test can be seen in the table 3.

Table 3. The Results of Product Effectiveness Tests

\begin{tabular}{clcl}
\hline No. & Effectiveness Test & $\begin{array}{c}\text { Percentage } \\
(\%)\end{array}$ & Criteria \\
\hline 1 & $\begin{array}{l}\text { Small Group } \\
(10 \text { students })\end{array}$ & 79.2 & Effective \\
2 & $\begin{array}{l}\text { Large Group } \\
\text { (30 students) }\end{array}$ & 77.6 & Effective \\
\hline
\end{tabular}

The results of the small group test (10 students) obtained a percentage of $79.2 \%$ and the results of the large group test (30 students) obtained a percentage of $77.6 \%$ or categorized as effective. Thus, based on the results of the field test, it was concluded that the product management model developed effectively was used to build students' self-resilience from drug abuse.

\section{Conclusion}

Based on the results of the research that has been carried out, it can be concluded that the management model to build students' self-resilience from drug abuse developed using the 4D development model proposed by Thiagarajan and Semmel, included the stage of define, design, develop, and disseminate. The product management model to build students' selfresilience from drug abuse developed has received assessment and validation from material expert and media expert, the results of the assessment state that the product is valid for use in building students' self-resilience from drug abuse, in terms of the feasibility of the content, language, presentation, display of modules and aspects of product feasibility. 
Products developed have also been tested for effectiveness in small groups (10 students) and large groups (30 students). The results of the effectiveness test show that effective product management models are used to build students' self-resilience from drug abuse. Thus it was concluded that the management model developed was in the valid and effective category used to build students' self-resilience from drug abuse.

The management model to build students' self-resilience from drug abuse is expected to be used as guidance for teachers, parents and students in an effort to build strong and positive self-resilience in facing various challenges and bad influence that come including the influence of drug abuse, so students have the ability and strength to say "no" to drugs.

\section{References}

[1] A. Kristanto, "Bentuk Dukungan Sosial Keluarga Terhadap Remaja Pengguna Narkoba (Studi Kasus di Yayasan Borneo Insan Mandiri Samarinda)," eJournal Ilmu Sosiatri, vol. 2, no. 3, pp. 64-76, 2014.

[2] S. Soedarsono, Penyemaian Jati Diri: Strategi Membentuk Pribadi, Keluarga, dan Lingkungan Menjadi Bangsa yang Profesional, Bermoral, dan Berkarakter. Jakarta: Elex Media Komputindo, 2000.

[3] H. Novilita and Suharnan., "Konsep Diri Adversity Quotient dan Kemandirian Belajar Siswa," J. Psikol., vol. 8, no. 1, pp. 619-632, 2013.

[4] I. Saputra, "Aktualisasi Nilai Pancasila Sebagai Kunci Mengatasi Penyalahgunaan Narkoba di Indonesia," J. Pancasila dan Kewarganegaraan, vol. 2, no. 2, pp. 25-35, 2017.

[5] A. Hanifah and N. Unayah, "Mencegah dan Menanggulangi Penyalahgunaan Napza Melalui Peran Serta Masyarakat," Informasi, vol. 16, no. 1, pp. 33-46, 2011.

[6] T. Ogur, M.M., Tarigan, B. M. Tinambunan, and E. Siswoyo, "Model Komunikasi Keluarga dalam Rangka Rehabiltasi Anak di Penjara Anak Perempuan; Studi Efektivitas Komunikasi Keluarga Untuk Penyembuhan Anak Narkoba di Penjara Tangerang," INSANI, vol. 1, no. 10, pp. 18-31, 2010.

[7] P. Masrokhan, Manajemen Mutu Sekolah. Jogjakarta: Ar-Ruzz Media, 2013.

[8] G. R. Terry and L. W. Rue, Dasar-Dasar Manajemen. Jakarta: Bumi Aksara, 2009.

[9] P. Setyosari, Metode Penelitian Pendidikan dan Pengembangan. Jakarta: Kencana, 2013.

[10] Trianto, Desain Pengembangan Pembelajaran Tematik. Jakarta: Bumi Aksara, 2014. 